\title{
Financial discourse of the 2007-2008 crisis: From unpredictability and explosion to predictability ${ }^{1}$
}

\author{
Griselda Zárate \\ Facultad de Humanidades y Ciencias Sociales, \\ Universidad Regiomontana \\ Matamoros 430 Poniente, Centro \\ CP 64000 Monterrey, N.L., México \\ e-mail: gzarate@u-erre.mx

\section{Homero Zambrano} \\ Department of Accounting and Finance, \\ Tecnológico de Monterrey, Campus Monterrey \\ Ave. Eugenio Garza Sada 2501, Col. Tecnológico, \\ CP 64849 Monterrey, N.L. México \\ e-mail: hzambranom@itesm.mx
}

\begin{abstract}
This paper aims to identify the inflection point in financial discourse, the moment of explosion and unpredictability in the 2007-2008 economic crisis, through an analysis of metaphors, and its relation to the concept of jumps in finance. The corpus is formed by articles dating from 2007-2008 published in The Wall Street Journal and related to the movements of the Standard \& Poor's 500 index (S\&P500) of the United States. For the purposes of this paper, two texts are analysed: "Traders in Lehman, AIG held out hope - Friday", and the speech "Four questions about the financial crisis" by Ben S. Bernanke. What is of particular interest is the transformation of unpredictability to predictability, as incorporated in this type of discourse to indicate a predetermined chain of events, chosen from a wide spectrum of possibilities. The theoretical framework draws on Juri Lotman's views on the concepts of explosion, unpredictability, inflection point and predictability.
\end{abstract}

Keywords: financial discourse; 2007-2008 economic crisis; unpredictability; inflection point; jumps; metaphors

An earlier version of this paper was presented at the Tartu Summer School of Semiotics / IX Conference of the Nordic Association for Semiotic Studies, "Semiotic (Un-)Predictability", 17-20 August, 2015, Tartu, Estonia. 


\section{Introduction}

This paper is a part of a larger research project and its aim is to identify the inflection point in financial discourse, the moment of explosion and unpredictability in the 2007-2008 economic crisis through the analysis of metaphors, and its relation to the concept of jumps in finance. ${ }^{2}$ The corpus consists of articles of specific dates of 2007-2008 published in The Wall Street Journal, related to the movements of the Standard \& Poor's 500 index (S\&P500) of the United States. This paper draws on the analysis of two texts: "Traders in Lehman, AIG held out Hope Friday" (Traders 2008) and the speech "Four questions about the financial crisis", by Ben S. Bernanke (US Federal Reserve), given after the crisis at the Morehouse College, Atlanta, Georgia, 14 April, 2009 (Bernanke 2009³). The focus is on the transformation of unpredictability to predictability, as incorporated in this type of discourse to indicate a predetermined chain of events chosen from a wide spectrum of possibilities. An interdisciplinary approach deriving from semiotics, argumentation and finance is adopted. Thus, the theoretical semiotic framework draws on Juri Lotman's views on the concepts of explosion, unpredictability, inflection point and predictability (Lotman 1999: 17-23, 28-33, 82, 170-174; 2000: 236; 2013: 68-70, 168).). From the point of view of discourse, this study is based on George Lakoff and Mark Johnson's concept of metaphor (Lakoff, Johnson 1980). The research incorporates financial theorist Eugene Fama’s (1970; 2008) views as stated in the Efficient Market Hypothesis, Robert Merton's (1976) jumpdiffusion model, and Suzanne Lee and Per Mykland's (2008) methodology of identifying jumps. The Efficient Market Hypothesis, implies that the price of an asset incorporates any new information immediately. Therefore, when a relevant piece of information is disclosed, the market adjusts accordingly in a magnitude that is not warranted by the ordinary market supply and demand variations; these abrupt changes are best modelled as jumps, as opposed to heavy-tailed diffusions (Cont, Tankov 2004).

\section{Literature review}

The use of language in finance and economics has been studied widely from the point of view of both finance and discourse studies, a previous work mentions

2 The role of metaphor and argumentation in financial discourse as regards the concept is studied in another work (Zárate, Zambrano, in print) through an operative model of argumentation based on Zárate 2015, Toulmin et al. 1979 and Gilbert 1997.

3 Bernanke, Ben S. Four questions about the financial crisis. April 14, 2009. Available at https://www.federalreserve.gov/newsevents/speech/bernanke20090414a.htm. 
the most significant papers in both disciplines related to this research (Zárate, Zambrano, in print). On the other hand, few studies have analysed the relation between finance and semiotics. Drawing on Peirce, Malloy (2000) describes the economic market as a sign and a sign system. Notably, Schinckus (2010) stresses the importance of a semiotic perspective in studying financial markets. A financial web blog in Australia, Macro Business, posted the article "The semiotics of markets" on 24 June, 2012, in which it discussed the metaphorical language used in the article "Economic epidemiology" published in The Economist on 16 June, 2012, as regards financial markets and terms such as contagion and virus. It is interesting to note the ending remarks on market behaviour in the latter article, "There is a final lesson: Expect the unexpected", which can be related to Lotman's views on unpredictability and the topic of this paper. ${ }^{4}$ Market Semiotics, a company in Vermont, United States, directed by Woody Dorsey, regularly publishes a business report on financial markets called Market Semiotics: Behavioral Market Diagnosis. It relies on the analysis of financial markets through Triunity Theory, a theoretical framework established by Dorsey. Three elements are studied: mood (psychological), body (technical), and mind (fundamentals). According to this theory, one of these three aspects is always in disequilibrium; investors make irrational decisions based on "slogan" words that reflect the overall market sentiment, which would still have an impact after the historical event. Some examples mentioned in the company brochure are the words 'terrorism' from 9/11, and then 'Iraq'. By reading the prospectus it can be deduced that newspaper articles or news in general are taken into account as a barometer of the financial market. It shows an analytic model, the Market Semiotics Memetic Model ${ }^{5}$, which can be identified on the third level in the metaphorical realm, the category in which metaphors are included as part of financial market analysis. Most recently, Ocula Journal (16 Dec. 2015) dedicated several papers to semiotics and economic discourse. De Oliveira-Verger's (2015) analysis is particularly interesting for the purposes of the present study as it focuses on the role played by shareholders during the 2008 crisis, and also stresses the emotional influence of the crisis.

\footnotetext{
4 The references can be found at http://www.macrobusiness.com.au/2012/06/the-semioticsof-markets/; http://www.economist.com/node/21556903.

5 The Market Semiotics' brochure containing the Memetic Model can be found at https:// www.sentimenttiming.com/wp-content/uploads/2014/06/MSBrochure.pdf.
} 


\section{Theoretical framework and methodology}

The theoretical framework has an interdisciplinary approach to cognitive metaphor in discourse studies, finance and semiotics. The aim is to explore an operative model of (un)predictability applied to financial discourse. In this paper the notion of financial discourse is identified as that which manifests an ideology of a group, usually of the upper strata, uses metaphors and includes emotional terms.

According to George Lakoff and Mark Johnson (1980: 3), the human conceptual system is mostly metaphorical, shaping the way thought is created; daily life and experiences rely on metaphorical construction. Common knowledge puts metaphors only in the literary realm, but metaphors help to conceptualize abstract ideas such as life, death, time (Lakoff, Turner 1989: 52-53). Some of the metaphors identified by Lakoff and Johnson (1980) in the conceptual system are: (1) Spatial orientation metaphors (fall, raise, upward, grow); (2) health metaphors (hurt, weak, insanity, depression); (3) natural forces metaphors (freeze, acid rain, tsunami, drought); (4) personification - objects and animals are persons. These types of metaphors have also been identified in financial discourse (e.g., "The markets are nervous today").

On the other hand, discourse as availability of information in finance can be found in Eugene Fama's Efficient Market Hypothesis, as he puts it: "[...] and investors can choose among the securities that represent ownership of firms' activities under the assumption that security prices at any time 'fully reflect' all available information. A market in which prices always 'fully reflect' available information is called 'efficient"' (Fama 1970: 383). In this sense, financial discourse is understood as financial statements, press releases, macroeconomic reports, news, etc. According to the informational content of discourse, prices, and thus returns, may change in a way that can be called "usual", barely discernibly, until we have huge variations due to obviously unexpected information, that has a severe impact on the asset's price, and/or on the market.

In 1976, Robert Merton proposed a concept of jumps in regards to financial processes: "[...] an option pricing formula is derived for the more-general cast when the underlying stock returns are generated by a mixture of both continuous and jump processes" (Merton 1976: 125). This is, returns (variation in prices of a stock), may undergo minor movements due to usual trading, and significant movements, due to the arrival of relevant information. Merton devised a theoretical model, the jump-diffusion model, in order to simulate future movements, which is relatively simple. The converse, i.e., telling a true jump from what is an atypical value in an actual diffusion process, is not that easy using real (historical) data. Recently, Lee and Mykland (2008) proposed a methodology to detect jumps 
in historical (past) series of returns of a stock, and statistically tell them apart from the usual (diffusive) movements. This paper relies on Lee and Mykland's methodology of detecting jump process in the financial crisis of 2007-2008.

Although Lee and Mykland's work is oriented to high-frequency data (intraday), they provide parameters to test to frequencies down to weekly data. Regarding data frequency, Cont and Tankov (2004) point out that whereas Brownian-Motionbased models (diffusion) are scale invariant, that is, they behave like fractals, intraday movements are basically jumps, and that there are discontinuities (jumps) even at monthly frequencies. News is archived on a daily basis and thus a higher frequency of asset prices would not be useful. In this article we use Lee and Mykland's methodology on daily S\&P500 levels (prices), to find jumps traceable to relevant pieces of information.

A semiotic perspective offers a more comprehensive view of discourse and its impact on finance. According to Lotman, a high degree of information is produced at the moment of explosion, which could be applied to the whole system (in this case, the financial discourse of the 2007-2008 crisis) and which is followed by an unpredictable and complex path. Special attention is paid to what this theorist expresses in regard to the inflection point, which he locates at the instant of exhaustion in the explosion process, thus, it is to say "the place of self-knowledge where history mechanisms intersect” (Lotman 1999: 29-30). The word 'jumps' is analogous in cultural and social explosions and can be related to its use in the discipline of finance as jump processes, which indicate sudden changes in stock prices. These jumps may be well latent in the underlying dynamics of the financial system, where there is hardly any logic in the events (see Talvet 2006: 51-52). This idea is worth exploring in this paper.

Based on this theoretical framework, in particular Lotman's ideas on (un)predictability, the article addresses the following issues: (1) the tension between unpredictability and predictability evident in financial discourse; (2) expression of the casual semiotic element integrated during the moment of explosion in the crisis of 2007-2008; (3) evidence of the inflection point in this explosive process in relation to financial discourse and volatility of the index market of 2007-2008; (4) manifestation of this dialectic through metaphors by means of attenuation or intensification discursive markers. This is carried out through the articulation and proposal of an (un)predictability operative model in this paper. 


\section{(Un)Predictability Operative Model}

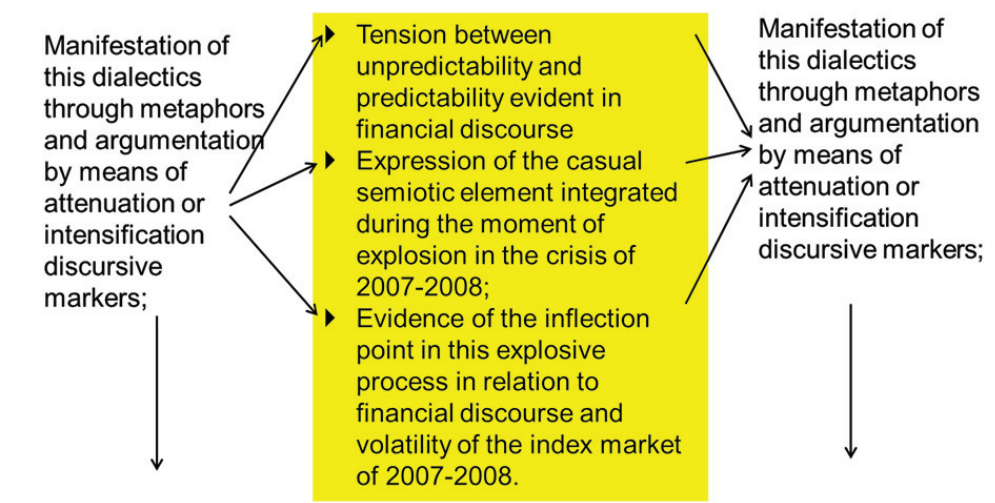

Unpredictability

Predictability

Figure 1. The (un)predictability operative model.

At the centre of the (un)predictability continuum lies the tension between these two poles in financial discourse. On one hand, it tends to prediction, on the other hand, there are unpredictable paths. It is at this moment of chaotic creativity and generation within the tension of both forces that a casual semiotic element takes form as the moment of explosion. Then, there is the inflection point in the explosive process of both unpredictability and predictability; thus, the evidence in financial discourse. Just one path, the predictable one, is visualized as the sole possibility, although there is myriad of possibilities of outcomes. But how is this done? At least for financial discourse, as it is explored in this paper, discursive markers and metaphors manifest this dialectics: first, as totally unpredictable, and then as predictable, the only possible outcome in a chain of events.

Vyacheslav Ivanov (2013: 9-10) wrote in his introduction to Lotman's The Unpredictable Workings of Culture: "Lotman's central idea can be reformulated in the spirit of Information Theory. In history and in the movement of cultures Lotman was most interested in those processes during which a maximal increase in the amount of information occurs. This directly explains the unpredictability of the processes Lotman describes as explosive." Ivanov's remarks on Lotman's unpredictability concept in the above quote is interesting in relation to financial discourse, given the fact that Eugene Fama's Efficient Market Hypothesis (Fama 1970) describes the role of availability of information on market prices as fully 
reflecting the market. Nevertheless, Fama (2008) mentions the unpredictability of financial returns on the basis of past returns, and thus it can be concluded that any increase in the financial information would result in unpredictability status in the financial markets.

\section{Discussion}

The corpus observed is formed by articles that were published in The Wall Street Journal on specific dates of 2007-2008, and are related to the movements of the Standard \& Poor's 500 index (S\&P500) of the United States. Two sample texts are analysed: the article "Traders in Lehman, AIG held out hope - Friday" that was published on 15 September, 2008 (Traders 2008) and the speech "Four questions about the financial crisis" by Ben S. Bernanke (US Federal Reserve), given after the crisis at Morehouse College, Atlanta, Georgia (Bernanke 2009).

The period was chosen not only on the basis of the obvious historical transcendence, but also due to the availability of financial discourse elements concerning what arose as jumps in the levels of the S\&P500 index. In that period, the corresponding jumps' statistics was higher than that of any other jump in over almost two decades. Lee and Mykland (2008) note that there are more jumps in single stocks than in a broad index such as the S\&P500; this is because a firm can be affected by idiosyncratic events such as the death of its CEO, or by events pertaining only to its sector or industry. The market shows jumps only in the presence of events that affect all of its components or at least the major players. This stylized fact only underlines the relevance of the jumps found in this period.

In order to find the jumps in the S\&P500, we used weekly data on the level of that index, starting on the first week of 1950, for a total of 3,481 observations. In accordance with Lee and Mykland, we used a window of seven observations, i.e., the first statistic was calculated for the week starting on 20 February 1950. Since we are working on the low end of the frequencies listed by the authors, we cannot assume that the drift (expected change) between observations is zero; therefore, we applied the corresponding modification to the test statistic. We used a confidence level of $95 \%$. Jumps were found on the weeks starting on 9 February 2008; 29 September 2008; and 6 October 2008.

It is important to note that even though jumps obviously correspond to weeks with high absolute values of return (measured as the natural logarithmic change of price), the converse is not necessarily true. For example, the week starting on 4 November 2008 witnessed a larger absolute return than that of 29 September 2008, yet the former did not include what could be considered a jump. This happened because jumps are associated with new information, but the high standard 
deviation of returns persists; this is known as volatility clustering, as captured by models such as the Generalized Auto Regressive Conditional Heteroscedasticity (GARCH), as devised by Robert F. Engle in 1982 (Engle 1982). In our date range, jumps occurred in contiguous weeks, and returns ranking in the top $10 \%$ of all returns since 1950 showed up in the ensuing seven weeks. As Fama (1970) implies, for discourse to have an impact on securities' prices, the information must be unpredictable. Otherwise, the market would have been incorporating the information into prices as soon as elements to build the forecast were gathered.

\subsection{Tension between unpredictability and predictability evident in financial discourse}

The application of the (Un)Predictability Operative Model in financial discourse during the 2007-2008 crisis shows that tension between unpredictability and predictability evident in financial discourse exhibits specific discursive markers as regards unpredictability. These can be found in the left-hand column in Fig. 1; the text "Traders in Lehman, AIG held out hope - Friday", WSJ, 15 Sept, 2008 expresses them as follows:

"If a year of maddening volatility has taught options traders anything, it's to expect the unexpected"

"The Wall Street Journal reported that prospective bidders were tentative, and hoped for government support, none of which suggested a rich premium"

"Some extreme bearish trades, balanced by some bets on a rebound [...]"

"For the bears, 'Lehman's kind of done, Washington Mutual's kind of done. It's happening pretty quickly"

On the other hand, predictability, in the right-hand column in Fig. 1, is, in case of the text "Four questions about the financial crisis" by Chairman Ben S. Bernanke Federal Reserve (USA), 14 April, 2009, expressed by the following:

"Historical experience shows that, once begun, a financial panic can spread rapidly and unpredictably; indeed, the failure of Lehman Brothers ${ }^{6}$ a day earlier [Sep 15], which the Fed and the Treasury unsuccessfully tried to prevent, resulted in the freezing up of a wide range of credit markets, with extremely serious consequences for the world economy.

The crisis deepened last September, when the failure or near failure of several major financial firms caused many financial and credit markets to freeze up."

6 In the realm of popular culture, the children's movie Despicable Me (2010) mentions "the Bank of Evil, formerly known as Lehman Brothers". 


\subsection{Expression of the casual semiotic element during the moment of explosion in the crisis of 2007-2008}

Lotman (1999: 19; 2013: 64). establishes that a continuous process has an implicit predictability, a process which manifests a cyclical or a gradual evolution, in contrast to unpredictability during an explosive process (Lotman 1999: 19; 2013: 64). In financial discourse, this is a promising field of exploration as continuous processes in finance, in the sense of system stability, are thus seen as predictable. However, jump processes, whether negative or positive, tend to appear suddenly on financial horizons. Following Lotman (1999: 17-18), it can be said that both predictable and unpredictable financial processes are the two extreme ends of the same frequency. As to finance, it is worth citing Fama's remarks on unpredictability: "...returns are unpredictable on the basis of past returns". Past returns are water under the bridge. Predictability of returns depends on the predictability of new information. Is it feasible? Would you trust your wealth to a fortune-teller?

Still, it is worthwhile mentioning what Lotman has noted in regards to unpredictability during the moment of explosion, just before an event is fulfilled. If one looks at this event from the past towards the future, the present is conceived as a whole series of probable possibilities, but this changes completely when the event is seen from the present towards the past - it becomes a fact, it is then seen as the only possibility (Lotman 1999: 172). Unpredictability takes form between the present and its projection in the future (Lotman 2013: 168).

\subsection{Evidence of the inflection point in this explosive process in relation to financial discourse and volatility of the index market of 2007-2008}

According to Lotman (2013: 69), it is at the moment of explosions that move between spheres and are thus particularly influential, that metaphors take form in discourse. It is interesting to note the importance of this in financial markets, in particular stock markets, where various kind of metaphors (personification, animalization, health metaphors, natural forces metaphors) emerge at the moment of explosion, the point of inflection. It can be expected that the stronger the discourse ("shockingness" of news or statements), the higher the probability of a jump (even right after another one). For example, as shown previously in the text "Traders in Lehman, AIG held out hope - Friday", (WSJ, 15 Sept, 2008), this unpredictability is found in discursive expressions such as "maddening volatility",

7 On 10 October 2008, Fama gave a talk at the University of Chicago, titled "A brief history of the Efficient Market Hypothesis", in which he explained how he came to the Efficient Market Hypothesis. See http://www.afajof.org/details/video/6028581/Eugene-Fama-The-History-ofthe-Efficient-Market-Hypothesis.html. 
"it's to expect the unexpected", "prospective bidders were tentative, and hoped for government support", "Some extreme bearish trades", "For the bears, 'Lehman's kind of done, Washington Mutual's kind of done. It's happening pretty quickly"'. These phrases are the manifestation of this dialectics through metaphors and argumentation by means of attenuation or intensification discursive markers regarding unpredictability. Conversely, predictability in discourse understood as a way to make sense of the financial crisis of 2007-2008 is described by the US Federal Reserve Chairman (Bernanke 2009) in words emphasizing it, for example: "Historical experience shows that, once begun, a financial panic can spread rapidly and unpredictably [...]", "At that time, [2008] the strains in the global financial system were unprecedented and extreme, [...]". So, from the present, being 2009 in the case of Bernanke's speech, to the past, being 2008, the financial crisis of 2007-2008 is understood and seen as the only possible outcome of the events during that year.

\section{Conclusion}

It can be concluded that in financial markets, in particular stock markets, various kinds of cognitive metaphors (personalization, animalization, health metaphors, natural forces metaphors) appear at the moment of explosion, the point of inflection. Such usage was detected in both texts analysed in this paper: "Traders in Lehman, AIG held out hope - Friday" (2008), and "Four questions about the financial crisis" (Bernanke 2009).

Jumps in finance reflect the arrival of shocking news, whether positive or negative. Jump-diffusion models represent market movements for the purpose of a more realistic simulation, generally for the purpose of securities' pricing. Diffusive aspects correspond to market quiet states (with no relevant information, just usual trading), while jumps correspond to relatively relevant news, which must be unexpected, i.e., true news. There may be jumps at the level of the company (due to unpredictable events affecting that company in particular), jumps at the sector or industry level (due to information not forecast that impinges on whole areas of the economy), and jumps at the market level (deriving from broad, transcendental information that most - if not all - companies care about). However, models are only an attempt to portray reality. In practice, identifying jumps is a somewhat convoluted mathematical process, because Gaussian diffusion processes do not preclude large - or even infinite - movements; however, when jumps are identified at different statistical significance levels in real, historical prices, and are present at the market level, they must be related to a very transcendental, unpredictable piece of information. 
Jumps can be the result of a statement or vice versa, when qualifying the movement. An interesting area of further research would be assessing the power of information over the market in a normative fashion, in order to avoid, or at least mitigate, verbal manipulation of securities' prices.

\section{References}

Cont, Rama; Tankov, Peter 2004. Financial Modelling with Jump Processes. Boca Raton: Chapman \& Hall/CRC.

De Oliveira-Verger, Christelle 2015. Sémiotique des phénomènes économiques de crise. Le rôle-clé de "l'actionnaire" dans la crise financière de 2008. Ocula 16.

Engle, Robert F. 1982. Autoregressive conditional heteroscedasticity with estimates of variance of United Kingdom inflation. Econometrica 50(4): 987-1008.

Fama, Eugene Francis 1970. Efficient capital markets: A review of Theory and empirical work. The Journal of Finance (Papers and Proceedings of the Twenty-Eighth Annual Meeting of the American Finance Association New York, N.Y. December, 28-30, 1969) 25(2): 383-417.

Gilbert, Michael A. 1997. Coalescent Argumentation. Mahwah: Lawrence Erlbaum Associates.

Ivanov, Vyacheslav V. 2013. Preface. In: Lotman, Juri, The Unpredictable Workings of Culture. (Baer, Brian James, trans.) Tallinn: Tallinn University Press, 7-16.

Lakoff, George; Johnson, Mark 1980. Metaphors We Live By. Chicago: The University of Chicago Press.

Lakoff, George; Turner, Mark 1989. More than Cool Reason: A Field Guide to Poetic Metaphor. Chicago: The University of Chicago Press.

Lee, Suzanne S.; Mykland, Per A. 2008. Jumps in financial markets: A new nonparametric test and jump dynamic. The Review of Financial Studies 21(6): 2535-2563.

Lotman, Juri M. 1999. Cultura y explosión: Lo previsible y lo imprevisible en los procesos de cambio social. (Muschietti, Delfina, trans.) Barcelona: Gedisa.

- 2000. Universe of the Mind: A Semiotic Theory of Culture. (Shukman, Ann, trans.) Bloomington: Indiana University Press.

- 2013. The Unpredictable Workings of Culture. (Baer, Brian-James, trans.) Tallinn: Tallinn University Press.

Malloy, Robin Paul 2000. Law and Market Economy: Reinterpreting the Values of Law and Economics. Cambridge: Cambridge University Press.

Merton, Robert C. 1976. Option pricing when underlying stock returns are discontinuous. Journal of Financial Economics 3: 125-144.

Schinckus, Christophe 2010. Semiotics of financial marketplace. The Journal of Interdisciplinary Economics 22: 317-333.

Talvet, Jüri 2006. Describir la modernidad: Gracián, Ortega, Lotman. Revista Entretextos 1: $44-52$.

Toulmin, Stephen; Rieke, Richard; Janik, Allan 1979. An Introduction to Reasoning. New York: Macmillan Publishing.

Traders in Lehman, AIG held out hope - Friday. The Wall Street Journal, 15 September, 2008.

Zárate, Griselda 2015. Argumentación en los textos de Andrea Villarreal (1907-1910). Lenguas en Contexto 12: 173-184. 
Zárate, Griselda; Zambrano, Homero (in print). Metáfora y argumentación en el discurso de la crisis financiera de 2007-2008. In: Salgado Andrade, Eva; Hernández Ruiz, Laura (eds.), Estudios del discurso en México: nuevas prácticas, nuevos enfoques. Mérida: CEPHCIS / UNAM.

\section{Финансовый дискурс кризиса 2007-2008: от непредсказуемости и взрыва к предсказуемости}

Статья стремится определить точку поворота в финансовом дискурсе, момент взрыва и непредсказуемости во время кризиса 2007-2008 гг, посредством анализа метафор и их отношений к понятию финансовых скачков. Корпус текстов сформирован статьями из Wall Street Journal, связанных с движениями индекса Standard \& Poor's 500 (S\&P500) Соединенных Штатов. Подробнее проанализированы два текста: “Торговцы в банке Lehman Brothers, AIG дала надежду - в пятницу”, (WSJ, 15 сентября 2008), и речь “Четыре вопроса о финансовом кризисе” Бена С. Бернанке (Федеральный резерв США), произнесенная после кризиса в Морхаус-Колледже, Атланта, Джорджия, 14 апреля 2009. Особый интерес представляет преобразование непредсказуемости в предсказуемость в этом типе дискурса, чтобы указать на предопределенную цепь событий, выбранных из широкого спектра возможностей. Теоретическая структура основывается на понятиях Юрия Лотмана о взрыве, непредсказуемости, точки бифуркации и предсказуемости.

\section{7-2008. aasta finantsdiskursus: ennustamatusest ja plahvatusest ennustatavuseni}

Artikli eesmärk on metafoorianalüüsi ning selle finantsvallas toimuvate hüpete mõistega seostamise kaudu teha kindlaks murdepunkt finantsdiskursuses, plahvatuse ja ennustamatuse hetk 2007-2008. aasta majanduskriisis. Vaadeldava korpuse moodustavad 2007-2008. aastal Väljaandes The Wall Street Journal konkreetsetel kuupäevadel ilmunud artiklid, mis on seotud Ameerika Ühendriikide Standard \& Poor’s 500 (S\&P500) indeksi liikumistega. Artiklis analüüsitakse kaht teksti: "Traders in Lehman, AIG held out hope - Friday" (WSJ, 15. sept. 2008) ning USA keskpanga Föderaalreservi juhatuse esimehe Ben Bernanke kõnet "Four questions about the financial crisis", mille ta kriisijärgselt (14. aprill, 2009) pidas Morehouse College'is Atlantas, Georgia osariigis. Erilist huvi pakub ennustamatuse teisenemine ennustatavuseks seda tüüpi diskursusesse kaasatuna, tähistamaks laiast võimalustespektrist valitud ettemääratud sündmusteahelat. Teoreetiline raamistus lähtub Juri Lotmani vaadetest plahvatuse, ennustamatuse, murdepunkti ja ennustatavuse mõistetele. 